\title{
An Empirical Model for the Raw Wood Assortment Price Predicting - Case Study in Slovakia
}

\author{
Miloš Gejdoš, ${ }^{\mathrm{a}, *}$ Marek Trenčiansky, ${ }^{\mathrm{b}}$ Blanka Giertliová, ${ }^{\mathrm{b}}$ Martin Lieskovský, ${ }^{\mathrm{a}}$ and \\ Zuzana Danihelovác
}

\begin{abstract}
Sales of timber, which represent the main source of forest management income, are essential for the economic welfare of forest businesses. Planning the timber sale management faces a certain amount of uncertainty and risk in such difficult conditions of climate change. Model scenarios make preparation for potential future development possible. The aim of the study was to create a prediction model of coniferous and nonconiferous sawlogs for the area of the Central Europe. The objective of the model was to estimate the variations in the price of coniferous or nonconiferous sawlogs following a linear regression equation in the analysed time series from 2001 to 2017. The price of coniferous sawlogs was significantly affected in a negative way by the amount of incidental fellings and in a positive way by the Gross Domestic Product. The price of the nonconiferous sawlogs was significantly affected in a positive way by the GDP and the volume of non-coniferous sawlog export. These factors caused a non-elastic response of the coniferous sawlog price. The impact of these factors depends to a great extent on the wood species composition of the forests in the Slovak Republic. The model also can be set for conditions of other countries when considering their economic indicators.
\end{abstract}

Keywords: Raw wood assortments; Timber prices; Prediction; Timber market; Incidental felling

Contact information: a: Technical University of Zvolen, Faculty of Forestry, Department of Forest Harvesting, Logistics and Ameliorations, T. G. Masaryka 24, Zvolen 960 01, Slovakia; b: Technical University of Zvolen, Faculty of Forestry, Department of Economics and Management of Forestry, $T$. G. Masaryka 24, Zvolen 960 01, Slovakia; c: Technical University of Zvolen, Institute of Foreign Languages, T.G. Masaryka 24, Zvolen 960 01, Slovakia; *Corresponding author: gejdos@tuzvo.sk

\section{INTRODUCTION}

Forest ecosystems worldwide are exposed to the adverse impacts of global climate change. Weather extremes (long-term droughts, spring frosts, gales, etc.) along with the outbreak of biotic pests (bark beetles, defoliators) have significantly decreased the stability of forest ecosystems in the last decade (Biber et al. 2015; Seidl et al. 2017; De Grandpre et al. 2018; Garcia-Valdes et al. 2018). In the case of forest management, these factors can be taken into consideration only with huge difficulties. The mentioned factors pose a great challenge for forest managers. Forest management is often focused on maximising the production and providing forest ecosystem services over longer time periods (periods longer than 100 years). The time stability and capability of responding is crucial in this situation (Yousefpour et al. 2015; Albrich et al. 2018). Only few forest ecosystems are influenced by the climate change to a small extent or do not need an immediate change of management (Jandl et al. 2019). Timber sale, presenting the main source of forest management incomes, is essential for the economic welfare of forest businesses (Gejdoš et al. 2019; Santos et al. 2019). Thus, planning the timber sale management faces a certain 
amount of uncertainty and risk in such difficult conditions of global climate change (Holécy and Hanewinkel 2006; Hanewinkel et al. 2013; Trubins et al. 2019). Model scenarios make preparation for potential future development possible. They are always hypothetical and determine the future situations, and their occurrence is not certain but incidental (Mozgeris et al. 2019). For designing the models and scenarios for predicting the timber prices and timber market, researchers have to be familiar with its previous developments, mainly how the market behaved in similar crisis situations (Gejdoš and Potkány 2017; Gejdoš et al. 2019). Along with incidental natural factors, economic, and social criteria are important in these models as well (Malinen et al. 2015; Merganič et al. 2016). Several studies have dealt with creating prediction models for timber prices affected by incidental fellings and weather extremes (Hanewinkel et al. 2013; Kostadinov et al. 2014; Brunette et al. 2015; Gejdoš et al. 2019). Most of the models are based on stochastic statistical models. Hanewinkel et al. (2019) show that forecasted changes in temperature and precipitation may have severe economic consequences. On the basis of their model results, the expected value of European forest land will decrease owing to the decline of economically valuable species in the absence of effective countermeasures. They found that by 2100 - depending on the interest rate and climate scenario applied - this loss varies between 14 and 50\% (mean: 28\% for an interest rate of 2\%) of the present value of forest land in Europe, excluding Russia. Kostadinov et al. (2014) discuss the potential of applying agent-based modeling to wood markets. The model includes wood-producing agents, such as public foresters and private forest owners, roundwood-consuming agents, such as sawmills, different classes of wood fuel consumers, and in-between wood traders. Brunette et al. (2015) propose an actuarial insurance model to insure multiple natural hazards (windthrow, fire, insect outbreak) in forests that determine the insurance premium in different scenarios. They propose two different links for the hazards mutually dependent or independent. In addition, they propose two parametric solutions, a discrete time period approach or a continuous one. The most efficient solution is obtained when assuming mutually independent natural hazards and a continuous time period approach. Such a solution provides gross insurance premiums ranging from $€ 5.62 /$ ha. Gejdoš et al. (2019) used the stochastic model ARIMA with an autocorrelation coefficient for raw-wood assortment prices predicting the future development. Prediction of the future timber price development made by this model was identified as the most probable one. In addition, information on the local business relationships and forest logging potential in individual countries is important, too.

However, only a few of them consider the long-term previous price development of raw wood assortments in more countries in one region. The models include mainly the price development of a shorter time period in one country and production cost optimisation in various scenarios in forest ecosystem management. Another reason is also the difficulty of comparing the prices of raw wood assortments caused by different quality requirements in individual countries (Malinen and Kilpeläinen 2013).

The aim of the study was to create a prediction model of coniferous and nonconiferous sawlogs in the conditions of the Slovak Republic, based on longitudinal observations of price development and considering the extreme impacts of incidental factors in the past decades.

The results of the study should represent a model providing the predicted price of coniferous and non-coniferous sawlogs in the future, considering the size and the intensity of the incidental factors affecting the forest ecosystem. The objective of the model was to estimate the variations in the price of coniferous or non-coniferous sawlogs following a 
linear regression equation in the analysed time series from 2001 to 2017. Model quantification enabled authors to solve the equation, i.e., to calculate the values of the response variable (price of the coniferous sawlogs, price of the non-coniferous sawlogs) depending on the explanatory variables (factors affecting the price of the coniferous or non-coniferous sawlogs).

The aim was to design a model that would reflect the current tree species composition of the temperate zone forests and the impact of negative factors. Such a model that is based on a previous long-term price development in the conditions of global climate change has not been published so far in any scientific literature.

\section{EXPERIMENTAL}

\section{Materials and Methods}

Prices of raw wood assortments

Information on the nominal prices of coniferous and non-coniferous sawlogs was obtained and collected from the Forestry Market Information System issued quarterly by the National Forestry Centre in Zvolen (Slovakia) and is available online (2019). The sawlog product range was selected due to its high ratio in the assortment structure in the long term, regarding the coniferous (the highest ratio) and non-coniferous wood species (the second highest ratio). The prices were in $€ \cdot \mathrm{m}^{-3}$ without value-added tax (VAT) for the dispatching supplier yard and were evaluated for individual months for the years of 2001 to 2017. The prices before this year were recalculated using the average monthly exchange rate Slovak crown/ $€$ by the National Bank of the Slovak Republic (2019). The average annual prices were calculated from these prices, as some variables (e.g., growth domestic product, volume of incidental fellings) of the model under consideration were evaluated only at annual intervals. Euro as a currency has been used in Slovakia since 2009. The created database of prices development was a complex input database, which was unique and has not been published in any scientific studies so far. The data were not statistically modified, nor was the impact of inflation during the monitored period considered. Therefore, the prices mirrored better the influence of the specific period and factors that occurred during the period and affected the timber prices.

\section{Empirical model creation}

The objective of the model was to estimate the variations in the price of coniferous or non-coniferous sawlogs following a linear regression equation in the analysed time series from 2001 to 2017.

Following a theoretical formulation of relations and selection of the response and potential explanatory variables, the general linear equation of the model of coniferous (nonconiferous) sawlog price is as follows in Eq. 1,

$$
Q_{\mathrm{t}}=a+b_{1} \cdot f_{1(\mathrm{t})}+b_{2} \cdot f_{2(\mathrm{t})}+\ldots+b_{\mathrm{k} \cdot} f_{\mathrm{k}(\mathrm{t})}+u_{\mathrm{t}} \quad(t=1,2, \ldots ., \mathrm{n})
$$

where $Q_{\mathrm{t}}$ is price (€. $\mathrm{m}^{-3}$ ) of coniferous (non-coniferous) sawlogs in the monitored year $t$, $f_{1-\mathrm{k}(\mathrm{t})}$ are factors affecting the price of coniferous (non-coniferous) sawlogs in the year $t, a$ is absolute member of the model, $b$ is estimated parameters of the independent variables, $u_{\mathrm{t}}$ is incidental element of the model in the year $t, k$ is the number of factors affecting the price of coniferous (non-coniferous) sawlogs, and $n$ is the number of observations. 
When creating the model, the impact of the delayed variables from the previous period was considered. To estimate the model parameters, the method of least squares and its characteristics was used (Turner and Buongiorno 2004). The statistical significance and information value of individual model parameters as well as the whole model was determined by testing the econometric models. At the same time, fulfilling the assumptions about the characteristics of the incidental element of the model and about independence of explanatory variables was tested. Within the economic interpretation of the model, the factors affecting the price of the coniferous (non-coniferous) sawlogs will be evaluated, average relative factor elasticities will be calculated, actual and estimated prices of coniferous (non-coniferous) sawlogs will be compared, and the impact of individual factors will be assessed. The final market timber price is influenced by the determinants of supply and demand for timber assortments. Timber supply is determined by the production capabilities of the forest enterprises and by the allowable cut, and it is also influenced by the amount of incidental felling. Demand for raw-wood assortments is derived from the demand for wood products and affected by the inland and overseas consumption of wood products. Potential factors affecting the price of coniferous and non-coniferous sawlogs are provided in Tables 1 and 2.

Statistical analyses were carried out using the Statistica software (Statsoft Inc., version 12, Praha, Czech Republic).

Table 1. Potential Factors Affecting the Price of Coniferous Sawlogs in the Slovakia

\begin{tabular}{|c|c|c|c|c|c|c|}
\hline Factor & $\begin{array}{c}\text { Factor } \\
\text { Abbrev. }\end{array}$ & Unit & Max. & Min. & Avg. & $\begin{array}{c}\text { Hypothesis } \\
\text { Influence on } \\
\text { Sawlog } \\
\text { Prices }\end{array}$ \\
\hline $\begin{array}{c}\text { Planned Coniferous Felling } \\
\text { Quantity }\end{array}$ & $\mathrm{Ei}$ & Thousand $\mathrm{m}^{3}$ & 4255 & 2517 & 3521 & - \\
\hline $\begin{array}{c}\text { Volume of Coniferous } \\
\text { Incidental Felling }\end{array}$ & $\mathrm{Ki}$ & Thousand $\mathrm{m}^{3}$ & 6151 & 1580 & 3796 & - \\
\hline $\begin{array}{c}\text { GDP (Current Prices) } \\
\text { Production of Coniferous } \\
\text { Sawnwood }\end{array}$ & $\mathrm{GDP}$ & BRillion $€$ & 85 & 34 & 63 & + \\
\hline $\begin{array}{c}\text { Coniferous Sawnwood } \\
\text { Consumption }\end{array}$ & $\mathrm{SRi}$ & Thousand $\mathrm{m}^{3}$ & 1803 & 134 & 877 & + \\
\hline $\begin{array}{c}\text { Export of Coniferous } \\
\text { Sawnwood }\end{array}$ & $\mathrm{Eri}$ & Thousand $\mathrm{m}^{3}$ & 1092 & 283 & 659 & + \\
\hline $\begin{array}{c}\text { Export Price for Coniferous } \\
\text { Sawnwood }\end{array}$ & $\mathrm{CERi}$ & Thousand & 490 & 90 & 232 & + \\
\hline Import of Conif. Sawnwood & $\mathrm{Iri}$ & Thousand $\mathrm{m}^{3}$ & 358 & 23 & 150 & - \\
\hline $\begin{array}{c}\text { Import Price for Coniferous } \\
\text { Sawnwood }\end{array}$ & $\mathrm{CIRi}$ & $\begin{array}{c}\text { Thousand } \\
\text { USD. } \mathrm{m}^{-3}\end{array}$ & 568 & 165 & 326 & + \\
\hline $\begin{array}{c}\text { Price Index for Wood } \\
\text { Products (Instant Prices } \\
\text { 2005) }\end{array}$ & $\mathrm{ICVD}$ & & 104 & 96 & 100 & + \\
\hline $\begin{array}{c}\text { Value of Construction } \\
\text { Production in Current Prices }\end{array}$ & $\mathrm{HSP}$ & Million $€$ & 6473 & 2609 & 4569 & + \\
\hline
\end{tabular}

Data on the planned and incidental fellings were obtained from the Green Reports of the Forest Management (Report on the forest sector of the Slovak Republic, Ministry of 
Agriculture and Rural Development of the Slovak Republic. 2019). The data on the wood products and their prices were collected using the database Food and Agriculture Organization of the United Nations - FAOSTAT (FAOSTAT 2018). Further data (GDP, price indexes) were processed using the Slovak statistical yearbooks of the Statistical Office of the Slovak Republic (2002 to 2018). Data on the value of production in constructions were processed using the Yearbooks of Construction Industry of the Ministry of Transport and Construction of the Slovak Republic (2019). All the data were summarised and evaluated via standard methods of database creation. Individual factors were selected to truly reflect their impact on the price of the coniferous and non-coniferous sawlogs.

Table 2. Potential Factors Affecting the Price of Coniferous Sawlogs in the Slovakia

\begin{tabular}{|c|c|c|c|c|c|c|}
\hline Factor & $\begin{array}{l}\text { Factor } \\
\text { Abbrev. }\end{array}$ & Unit & Max. & Min. & Avg. & $\begin{array}{l}\text { Hypothesis } \\
\text { Influence on } \\
\text { Sawlog } \\
\text { Prices }\end{array}$ \\
\hline $\begin{array}{c}\text { Planned Non-coniferous } \\
\text { Felling Quantity }\end{array}$ & $\mathrm{El}$ & Thousand $\mathrm{m}^{3}$ & 5493 & 3101 & 4297 & - \\
\hline $\begin{array}{l}\text { Volume of Non-coniferous } \\
\text { Incidental Felling }\end{array}$ & $\mathrm{KI}$ & Thousand $\mathrm{m}^{3}$ & 1847 & 301 & 687 & - \\
\hline $\begin{array}{l}\text { Volume of Coniferous } \\
\text { Incidental Felling }\end{array}$ & $\mathrm{Ki}$ & Thousand $\mathrm{m}^{3}$ & 6151 & 1580 & 3796 & - \\
\hline GDP (Current Prices) & GDP & Billion $€$ & 85 & 34 & 63 & + \\
\hline $\begin{array}{c}\text { Production of Non- } \\
\text { coniferous Sawnwood }\end{array}$ & PRI & Thousand $\mathrm{m}^{3}$ & 782 & 157 & 470 & + \\
\hline $\begin{array}{c}\text { Non-coniferous } \\
\text { Sawnwood Consumption }\end{array}$ & SRI & Thousand $\mathrm{m}^{3}$ & 909 & 380 & 578 & + \\
\hline $\begin{array}{c}\text { Export of Non-coniferous } \\
\text { Sawnwood }\end{array}$ & ERI & Thousand $\mathrm{m}^{3}$ & 282 & 50 & 137 & + \\
\hline $\begin{array}{l}\text { Export Price for Non- } \\
\text { coniferous Sawnwood }\end{array}$ & CERI & $\begin{array}{l}\text { Thousand } \\
\text { USD } \mathrm{m}^{-3}\end{array}$ & 1749 & 169 & 637 & + \\
\hline $\begin{array}{c}\text { Import of Non-coniferous } \\
\text { Sawnwood }\end{array}$ & $\mid \mathrm{Ir|}$ & Thousand $\mathrm{m}^{3}$ & 74 & 12 & 29 & - \\
\hline $\begin{array}{l}\text { Import Price for Non- } \\
\text { coniferous Sawnwood }\end{array}$ & $\mathrm{CIRI}$ & $\begin{array}{l}\text { Thousand } \\
\text { USD } \mathrm{m}^{-3}\end{array}$ & 1316 & 305 & 663 & + \\
\hline $\begin{array}{l}\text { Price Index for Wood } \\
\text { Products (Instant Prices } \\
2005)\end{array}$ & ICVD & & 104 & 96 & 100 & + \\
\hline $\begin{array}{l}\text { Value of Construction } \\
\text { Production in Current } \\
\text { Prices }\end{array}$ & HSP & Million $€$ & 6473 & 2609 & 4569 & + \\
\hline
\end{tabular}

\section{RESULTS AND DISCUSSION}

\section{Model for Coniferous Sawlog Prices}

Following the econometric analysis of the period of 2001 to 2017, the equation (Eq.

2) for calculating the coniferous sawlog price was designed as follows,

$$
C_{\mathrm{t}}^{\text {ihg }}=24.75-0.004 K \mathrm{i}_{\mathrm{t}}+0.76 G D P_{\mathrm{t}}
$$


where the dependent variable $C_{\mathrm{t}}^{\text {ing }}$ is the price $\left(€ . \mathrm{m}^{-3}\right)$ of the coniferous sawlogs in the year $t$, the independent variable $G D P_{\mathrm{t}}$ is the gross domestic product in prevailing prices (billion $€$ ), and $K \mathrm{i}_{\mathrm{t}}$ is volume of the coniferous incidental felling in the year $t$ (thousand $\left.\mathrm{m}^{3}\right)$.

The price of the coniferous sawlogs in the analysed time series varied in the interval of $40.05 € \cdot \mathrm{m}^{-3}$ (2005) to $69.88 € \cdot \mathrm{m}^{-3}$ (2013). The price of the coniferous sawlogs was significantly affected in a negative way by the amount of incidental fellings and in a positive way by the GDP. The increasing amount of processed incidental felling increased the offered amount of coniferous sawlogs, leading to a decrease in its prices. In contrast, an increase in GDP encouraged an increased demand for wood products, causing an increase in the prices of wood assortments. Figure 1 illustrates a comparison of the real prices of coniferous sawlogs with prices calculated using the regression equation in the time series from 2001 to 2017.

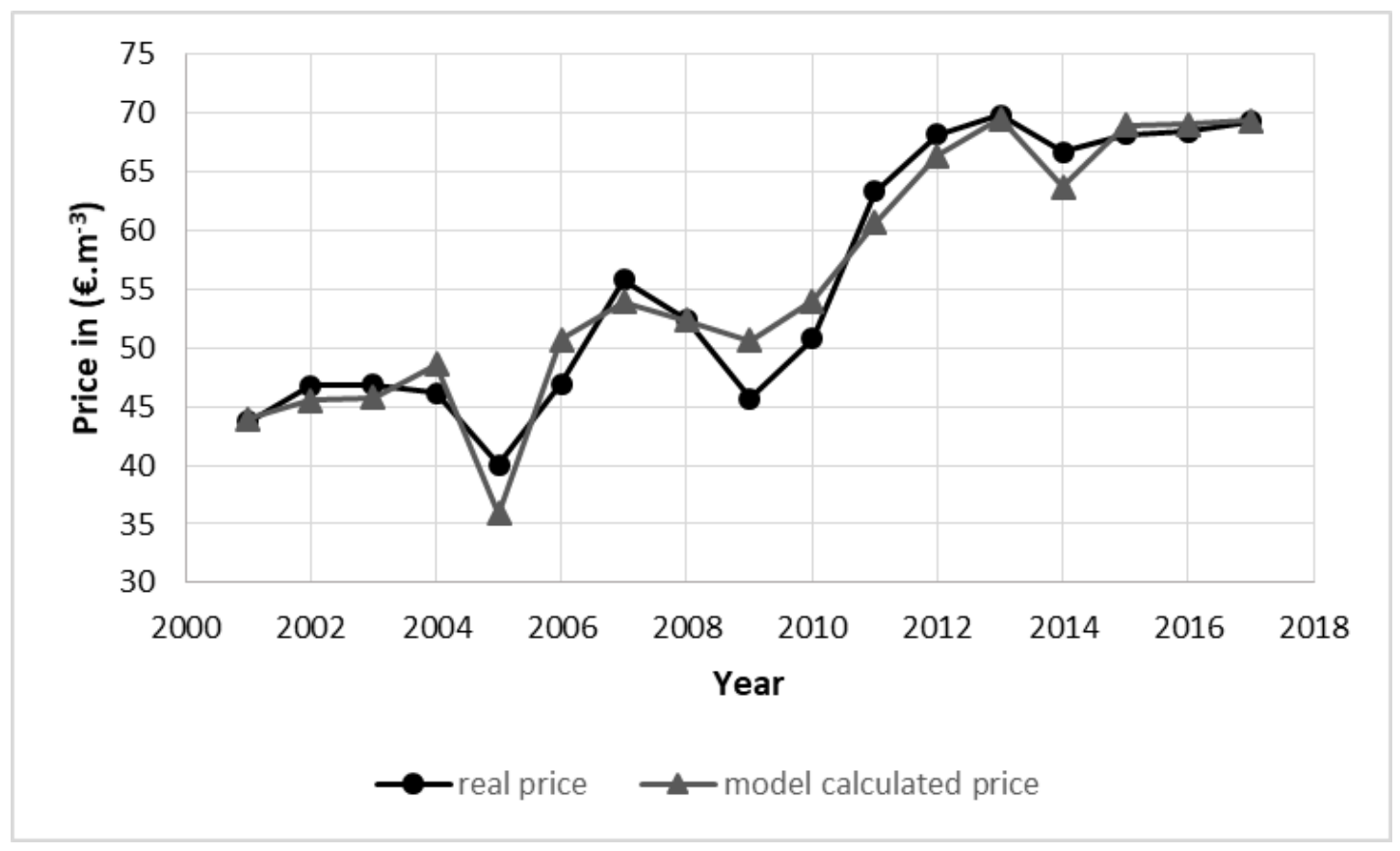

Fig. 1. Real and model calculated price for coniferous sawlogs during 2001 to $2017\left(€ \cdot \mathrm{m}^{-3}\right)$

Both factors (amount of incidental fellings, GDP) caused a non-elastic response of the coniferous sawlog price. If the amount of incidental fellings increases $1 \%$, the price of the coniferous sawlogs will decrease $0.3 \%$. If the GDP increases $1 \%$, the price of the coniferous sawlogs will increase $0.85 \%$. Significantly lower elasticity in the case of incidental fellings can indicate restricting the planned logging at the occurrence of incidental fellings. The factor of coniferous incidental fellings explained $33 \%$ of the variance in the dependent variable - price of the coniferous sawlogs, factor of GDP explained $67 \%$ (Beta coefficients).

Table 3 (part A) presents the statistical characteristics of the calculated model.

The econometric model and its regression parameters were statistically significant at the level $\alpha=0.05$. Multicollinearity tested by the Farrar-Glauber test (Akinniyi and Sanni 2017) $\chi^{2}=3.79$ (12.59) was not confirmed in the model. Autocorrelation of residuals in the model was tested by the Durbin-Watson test (White 1992) and Von Neumann ratio (Von 
Neumann 1941). The Durbin-Watson test did not prove the occurrence of autocorrelation of residuals ( $\mathrm{DW}=1.55)$. Von Neumann ratio proved the absence of autocorrelation of residuals in the model $(\mathrm{D}=1.65$, critical value 1.33 to 2.92$)$.

Table 3. Statistical Characteristics of Model - Price of Coniferous and Nonconiferous Sawlogs

\begin{tabular}{|c|c|c|c|c|c|}
\hline \multicolumn{6}{|c|}{ Coniferous Sawlogs - Part A } \\
\hline \multirow[b]{2}{*}{$N=17$} & \multicolumn{5}{|c|}{$\mathrm{R}=0.97369331, \mathrm{R} 2=0.94807867, \mathrm{~F}(2,14)=127.82, \mathrm{p}<0.00000$} \\
\hline & Coeff. $\beta$ & $\mathrm{b}$ & $\begin{array}{c}\text { Standard } \\
\text { Error From b }\end{array}$ & $\mathrm{T}(1) 4$ & p-value \\
\hline Absolute Term & & 24.75473 & 2.798068 & 8.84708 & 0.000000 \\
\hline $\begin{array}{c}\text { Volume of } \\
\text { Coniferous } \\
\text { Incidental Fellings }\end{array}$ & 0.33 & -0.00445 & 0.000574 & -7.74794 & 0.000002 \\
\hline $\begin{array}{l}\text { GDP (Current } \\
\text { Prices) }\end{array}$ & 0.67 & 0.76390 & 0.047778 & 15.98871 & 0.000000 \\
\hline \multicolumn{6}{|c|}{ Non-coniferous Sawlogs - Part B } \\
\hline & \multicolumn{5}{|c|}{$R=0.86906331, R 2=0.75527103, F(2,14)=21.603, p<0.00005$} \\
\hline$N=17$ & Coeff. $\beta$ & $\mathrm{b}$ & $\begin{array}{c}\text { Standard } \\
\text { Error From b }\end{array}$ & $\mathrm{T}(1) 4$ & p-value \\
\hline Absolute Term & & 27.75224 & 3.894807 & 7.125447 & 0.000005 \\
\hline $\begin{array}{l}\text { GDP (Current } \\
\text { Prices) }\end{array}$ & 0.77 & 0.30453 & 0.046395 & 6.563804 & 0.000013 \\
\hline $\begin{array}{l}\text { Export of Non- } \\
\text { coniferous } \\
\text { Sawnwood }\end{array}$ & 0.23 & 0.02915 & 0.011043 & 2.640075 & 0.019401 \\
\hline
\end{tabular}

\section{Model for Non-coniferous Sawlog Prices}

Following the econometric analysis of the period of 2001 to 2017, the equation for non-coniferous sawlog price was designed as follows (Eq. 3),

$$
C_{\mathrm{t}}^{\operatorname{ltg}}=27.75+0.305 G D P_{\mathrm{t}}+0.029 E R l_{\mathrm{t}}
$$

where the dependent variable $C_{\mathrm{t}}{ }^{\operatorname{ltg}}$ is price $\left(€ . \mathrm{m}^{-3}\right)$ of the non-coniferous sawlogs in the year $t$, the independent variable $G D P_{\mathrm{t}}$ is gross domestic product in prevailing price (billion $€$ ), and $E R l_{\mathrm{t}}$ is the export of the non-coniferous sawnwood in the year $t$ (thousand $\mathrm{m}^{3}$ ).

In the analysed time series, the price of the non-coniferous sawlogs varied in the interval of $41.91 € \cdot \mathrm{m}^{-3}$ (2005) to $58.90 € \cdot \mathrm{m}^{-3}$ (2017). The price of the non-coniferous sawlogs was significantly affected in a positive way by the GDP and the volume of nonconiferous sawlog export. In contrast to the coniferous sawlog model, the price of the nonconiferous sawlogs was not affected by the supply. The price was determined by the demand. Increased GDP and export caused an increased demand for wood products affecting the increase in wood assortment prices. The impact of factors was proved by the fact that the demand for wood was derived from the demand for wood products. Figure 2 illustrates the real prices of non-coniferous sawlogs and prices calculated using the regression equation in the time series from 2001 to 2017.

Both factors (GDP, amount of export of non-coniferous sawnwood) caused a nonelastic response of the non-coniferous sawlog price. An increase of $1 \%$ in GDP will cause an increase of $0.08 \%$ in the price of non-coniferous sawlogs. The factor of GDP explained as much as $77 \%$ of the dependent variable variance - price of the non-coniferous sawlogs; 
for the factor of export of non-coniferous sawnwood it was 23\% (Beta coefficients). Statistical characteristics of the calculated model are presented in Table 3 (part B).

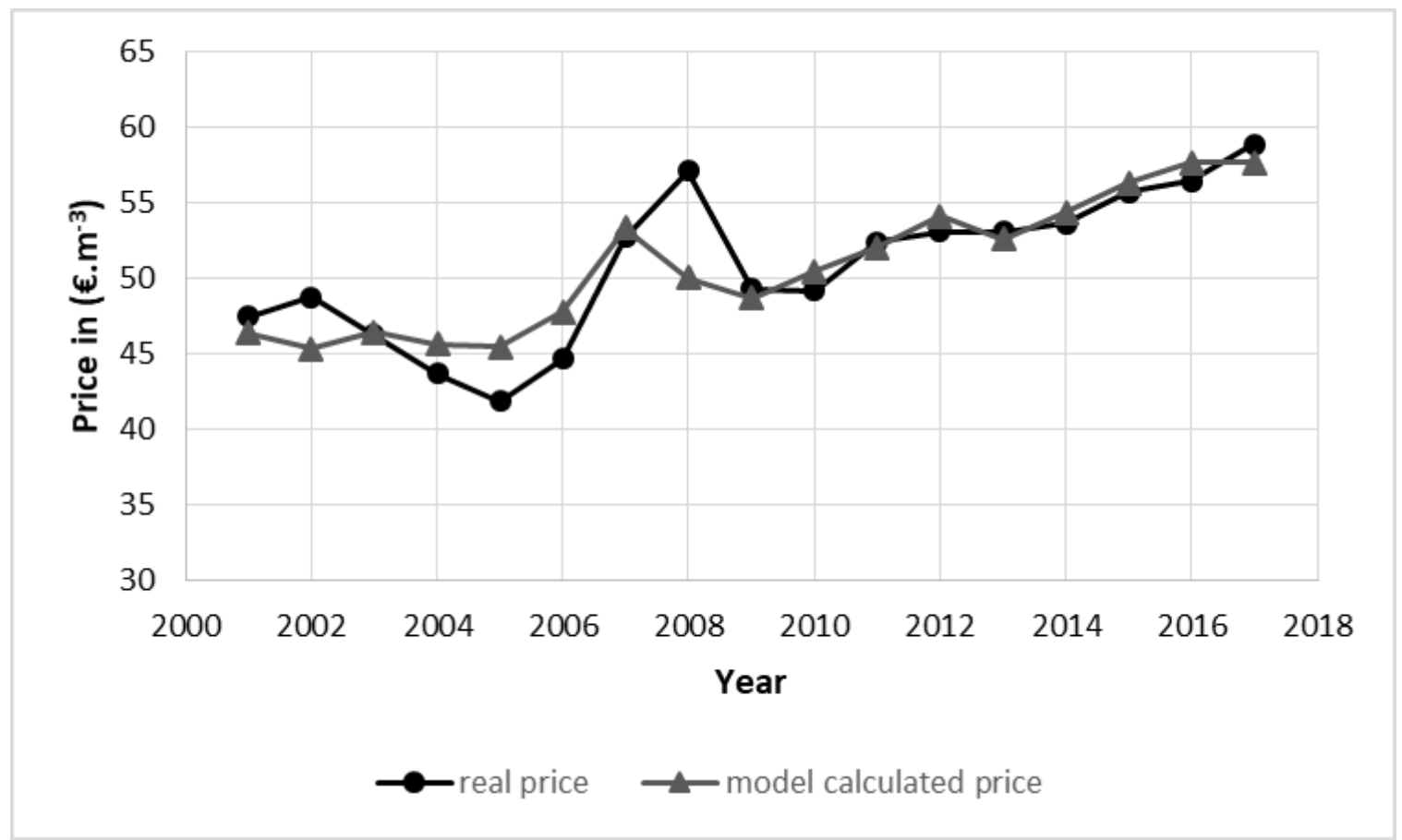

Fig. 2. Real and model calculated price for non-coniferous sawlogs in 2001 to $2017\left(€ \cdot \mathrm{m}^{-3}\right)$

The econometric model and its regression parameters were statistically significant at the level of $\alpha=0.05$.

Multicollinearity $\left(\chi^{2}=3.2(12.59)\right)$ and autocorrelation of residuals ( $\mathrm{DW}=1.55, \mathrm{D}$ $=1.65$, krit. 1.33 to 2.92 ) were not confirmed statistically in the model. Figures 1 and 2 along with the statistical analysis point at a relatively accurate setting of the model, which can thus serve as a good tool for predicting the timber prices in the current unstable market conditions. Therefore, it can present a fairly good tool for forest enterprise management in the long-term planning. The model can be set also for conditions of other countries when considering their economic indicators. The model presented a good theoretical background for designing similar models in the conditions of the Central Europe.

\section{Discussion}

The results of this study proved a significant impact on the prediction model of the prices of raw wood assortments considering the factors as GDP, export of the nonconiferous sawnwood, and amount of incidental coniferous felling. The impact of these factors depended to a great extent on the wood species composition of the forests in the Slovak Republic. Härtl and Knoke (2014) studied the impact of crude oil prices on timber prices. A significant decrease in oil prices caused a subsequent decrease in the prices of beech sawlogs only. Therefore, it cannot be considered as a significant factor for model design. The authors of this study predicted, considering various scenarios of oil price development, a more radical price increase until 2020 only for following categories: assortments of spruce pulpwood and fuelwood; class III. C of beech sawlogs; and pulp- 
and fuelwood. This prediction was proved also by the authors' results analysing the decrease in oil prices at the turn of 2014/2015.

Gejdoš et al. (2019), when calculating the prediction of sawlog prices, proved that the impact of vast windthrows on the prices of these assortments decreases significantly one year after the windthrow occurred and the impact is approximately $14 \%$ on average. They had a significant impact on the timber market within one year after they occurred. The study also demonstrated a clear impact of specific factors (e.g., unfavourable business contracts). However, when generalising the model for calculating the prices for a broader region, these impacts cannot be considered, because they are market-specific and are of incidental nature. This study, however, confirmed that the development of raw wood assortment prices in the Slovak Republic, Czech Republic, and Austria correlate and their development is with significant changes affected by almost identical factors. Similar situation is also in Germany. Following these results, the designed model can be partially generalized to a broader geographical area and to more countries in the Central Europe or to countries with similar tree species composition influenced by biotic and abiotic harmful factors of similar intensity.

Leskinen and Kangas (1998) designed a model for predicting the price development following the stochastic statistical model. This model was then used for creating a decision making concept for strategic management in timber trade, while using two further key factors - standing timber volume and net current value of revenues and costs for a decade (Kangas et al. 2000). However, these statistical models are based on long-term comparisons of price development or on questionnaire surveys. They do not thoroughly consider the impact of statistically tested and significant impact factors in the given period.

Gejdoš and Potkány (2017) predicted the price development in the Slovak Republic using the method of moving averages. The statistical analysis showed that $26 \%$ of the price variability is affected by the seasonal impacts and $73 \%$ is influenced by the price trends on the market, which corresponded approximately with the present model for predicting the prices of coniferous sawlogs.

Kostadinov et al. (2014) modelled the impact of forest area growth on the timber market in Switzerland considering the specific conditions of the country. The highest decline in timber prices was recorded in the case of 3.9\% growth of the forest area per year. In contrast, the highest increase in timber prices was predicted for the scenario with $1.3 \%$ growth of the forest area per year. However, the model was supplemented by the social criteria and preferences of individual sector consumers. Therefore, it cannot be applied generally to other markets.

Aguilar et al. (2014) assessed the impact of the logging methods in the USA in the prices of fuelwood and wood biomass. The statistical model was based on a questionnaire survey, which revealed that $38 \%$ of forest owners preferred integrated logging and harvesting technologies and 52\% did not want to log at all. Only $8 \%$ of owners preferred traditional logging methods. Such findings can affect the timber prices significantly in the future, as well, because in society there is a shift towards using non-production forest functions. The present model has not considered this variant, yet. The forest utilisation covers mainly the production functions, which are significantly affected by the amount of incidental fellings. 


\section{CONCLUSIONS}

1. The economic efficiency of forest enterprises in Slovakia is decreasing due to the increasing amount of incidental fellings, which is connected to a decrease in the wood quality and a missing qualified labour force. Traditional econometric statistical models predicting the prices are satisfactory in standard conditions.

2. The present study introduced a model considering relevant factors that have influenced the wood prices on regional markets for the past two decades. After modifying the model in terms of individual markets, it can be used also in other countries, at least in the Central European region, since the price development of raw wood assortment in the countries of this region show correlation and significant changes are affected by identical factors of macroeconomic development and impact of harmful factors. The present model confirmed a good prediction capability and can be thus a good tool for strategic management planning in forestry enterprises.

3. In the Slovak conditions, managements of many forestry enterprises significantly underestimated this strategic field and did not give it sufficient attention. In the end, it was reflected in their poor financial health, obsolete machinery, and lack of qualified staff. It also resulted in a poor public image of forestry and it will take long time and effort to improve this condition.

4. In present model the price of the coniferous sawlogs was significantly affected in a negative way by the amount of incidental fellings and in a positive way by the GDP. The price of the non-coniferous sawlogs was significantly affected in a positive way by the GDP and the volume of non-coniferous sawlog export.

5. The created prediction model reflected factors that were shown to have a statistically significant impact on the timber price development in the Slovak Republic in the past two decades. In the future, mainly in the next decade, it will be necessary to investigate the impact of such factors on the timber price development. After statistical verification, the designed model can be modified repeatedly for the current conditions. It created a good foundation for a future timber price prediction model that can be modified according to the requirements.

\section{ACKNOWLEDGMENTS}

The authors are grateful for the support of the Slovak Ministry of Education, Science, Research, and Sport of the Slovak Republic and the Slovak research and development agency (Grant Nos. VEGA Nr. 1/0031/18: Optimization of technological and work processes and risk assessment in the production of forest biomass for energy purposes; and APVV-18-0520: Innovative methods for analyzing the performance of wood and forestry complex using the principles of green growth). 


\section{REFERENCES CITED}

Aguilar, F. X., Cai, Z., and D’Amato, A. W. (2014). "Non-industrial private forest owner's willingness-to-harvest: How higher timber prices influence woody biomass supply," Biomass and Bioenergy 71, 202-215. DOI: 10.1016/j.biombioe.2014.10.006

Akinniyi, A. J., and Sanni, E. A. (2017). "The Farrar-Glaubar approach in testing for multicollinearity in economic data," International Journal for Research in Business, Management and Accounting 3(5), 1-17.

Albrich, K., Rammer, W., Thom, D., and Seidl, R. (2018). "Trade-offs between temporal stability and level of forest ecosystem services provisioning under climate change," Ecological Applications 28(7), 1884-1896. DOI: 10.1002/eap.1785

Biber, P., Borges, J. G., Moshammer, R., Barreiro, S., Botequim, B., Brodrechtová, Y., Brukas, V., Chirici, G., Cordero-Debets, R., and Corrigan, E., et al. (2015). "How sensitive are ecosystem services in European forest landscapes to silvicultural treatment?," Forests 6(5), 1666-1695. DOI: 10.3390/f6051666

Brunette, M., Holécy, J., Sedliak, M., Tuček, J., and Hanewinkel, M. (2015). “An actuarial model of forest insurance against multiple natural hazards in fir (Abies alba Mill.) stands in Slovakia," Forest Policy and Economics 55, 46-57. DOI: 10.1016/j.forpol.2015.03.001

De Grandpre, L., Waldron, K., Bouchard, M., Gauthier, S., Beaudet, M., Ruel, J. C., Hebert, C., and Kneeshaw, D. D. (2018). "Incorporating insect and wind disturbances in a natural disturbance-based management framework for the Boreal Forest," Forests 9(8), Article number 471. DOI: 10.3390/f9080471

Food and Agriculture Organization of the United Nations (FAO) (2019). "Forestry production and trade," (http://www.fao.org/faostat/en/\#data/FO), Accessed 18 June 2019.

Garcia-Valdes, R., Bugmann, H., and Morin, X. (2018). "Climate change-driven extinctions of tree species affect forest functioning more than random extinctions," Diversity and Distributions 24(7), 906-918. DOI: 10.1111/ddi.12744

Gejdoš, M., and Potkány, M. (2017). "Prediction and analysis of Slovakian timber trade on global market conditions," Serbian Journal of Management 12(12), 283-291. DOI: $10.5937 /$ sjm12-11228

Gejdoš, M., Lieskovský, M., Giertliová, B., Němec, M., and Danihelová, Z. (2019). "Prices of raw-wood assortments in selected markets of Central Europe and their development in the future," BioResources 14(2), 2995-3011. DOI: 10.15376/biores.14.2.2995-3011

Hanewinkel, M., Cullmann, D. A., Schelhaas, G. J., Nabuurs, G. J., and Zimmermann, N. E. (2013). "Climate change may cause severe loss in the economic value of European forest land," Nature Climate Change 3, 203-207. DOI: 10.1038/nclimate1687

Härtl, F., and Knoke, T. (2014). "The influence of the oil price on timber supply," Forest Policy and Economics 39, 32-42. DOI: 10.1016/j.forpol.2013.11.001

Holécy, J., and Hanewinkel, M. (2006). "A forest management risk insurance model and its application to coniferous stands in southwest Germany," Forest Policy and Economics 8, 161-174. DOI: 10.1016/j.forpol.2004.05.009

Jandl, R., Spathelf, P., Bolte, A., and Prescott, C. E. (2019). "Forest adaptation to climate change is non-management an option?," Annals of Forest Science 76(2), Article number 48. DOI: 10.1007/s13595-019-0827-X 
Kangas, J., Leskinen, P., and Pukkala, T. (2000). "Integrating timber price scenario modeling with tactical management planning of private forestry at forest holding level," Silva Fennica 34(4), 399-409. DOI: 10.14214/sf.621

Kostadinov, F., Holm, S., Steubing, B., Thees, O., and Lemm R. (2014). "Simulation of a Swiss wood fuel and roundwood market: An explorative study in agent-based modelling," Forest Policy and Economics 38, 105-118. DOI: 10.1016/j.forpol.2013.08.001

Leskinen, P., and Kangas, J. (1998). "Modelling and simulation of timber prices for forest planning calculations," Scandinavian Journal of Forest Research 13(4), 469476. DOI: $10.1080 / 02827589809383008$

Malinen, J., Haring, M., Kilpeläinen, H., and Verkasalo, E. (2015). "Comparison of alternative roundwood pricing systems - A simulation approach," Silva Fennica 49(3), Article ID 1293. DOI: 10.14214/sf.1293

Malinen, J., and Kilpeläinen, H. (2013). "Price systems for standing sales of industrial roundwood in Finland," Baltic Forestry 19(2), 307-315.

Merganič, J., Merganičová, K., Marušák, R., Tipmann, L., Šálek, L., Dragoun, L., and Stolariková, R. (2016). "Relation between forest stand diversity and anticipated log quality in managed Central European forests," International Journal of Biodiversity Science, Ecosystem Services and Management 12(1-2), 128-138. DOI: 10.1080/21513732.2016.1150883

Ministry of Agriculture and Rural Development of the Slovak Republic (2019). "Report on the forest sector of the Slovak Republic," Ministry of Agriculture and Rural Development of the Slovak Republic., (http://www.mpsr.sk/en/index.php?navID=17), Accessed 18 June 2019.

Ministry of Transport and Construction of the Slovak Republic (2019). "Yearbook for the constructions," Ministry of Transport and Construction of the Slovak Republic, (https://www.mindop.sk/ministerstvo-1/vystavba-5/stavebnictvo/dokumenty-amaterialy/rocenky-stavebnictva), Accessed 18 June 2019.

Mozgeris, G., Kavaliauskas, M., Brukas, V., and Stanislovaitis, A. (2019). "Assessment of timber supply under alternative contextual scenarios," Forest Policy and Economics 103, 36-44. DOI: 10.1016/j.forpol.2018.01.002

National Bank of Slovakia (2019). "Exchange rate of the Slovak national bank," NBS, (http://www.nbs.sk/sk/statisticke-udaje/kurzovy-listok/kurzovy-listok/priemernemesacne-kurzy-usd-a-eur-v-skk-kumulativne), Accessed 18 June 2019.

National Forestry Centre (2019). "Information list. Prices development for raw-wood assortments and delivering of raw-wood," Forest portal, (http://www.forestportal.sk/lesne-hospodarstvo/informacie-o-lesoch/trhovespravodajstvo/Informan\%20listy/1q2019.pdf), Accessed 18 June 2019.

Santos, A., Carvalho, A., Barbosa-Povoa, A. P., Marques, A., and Amorim, P. (2019). "Assessment and optimization of sustainable forest wood supply chains - A systematic literature review," Forest Policy and Economics 105, 112-135. DOI: 10.1016/j.forpol.2019.05.026

Seidl, R., Thom, D., Kautz, M., Martin-Benito, D., Peltoniemi, M., Vacchiano, G., Wild, J., Ascoli, D., Petr, M., and Honkaniemi, J., et al. (2017). "Forest disturbances under climate change," Nature Climate Change 7(6), 395-402. DOI:

10.1038/NCLIMATE3303 
Statistical Office of the Slovak Republic (2002-2019). "Statistical yearbook for the Slovakia regions," Statistical Office of the Slovak Republic, (https://slovak.statistics.sk/wps/), Accessed 18 June 2019.

Trubins, R., Jonsson, R., Wallin, I., and Salinas, O. (2019). "Explicating behavioral assumptions in forest scenario modelling - the behavioral matrix approach," Forest Policy and Economics 103, 70-78. DOI: 10.1016/j.forpol.2017.07.001

Turner, J. A., and Buongiorno, J. (2004). "Estimating price and income elasticities of demand for imports of forest products from panel data," Scandinavian Journal of Forest Research 19(4), 358-373. DOI: 10.1080/02827580410030127

Von Neumann, J. (1941). "Distribution of the ratio of the mean square successive difference to the variance," Annals Mathematical Statistics 12(4), 367-395. DOI: $10.1214 /$ aoms/1177731677

White, K. J. (1992). "The Durbin-Watson test for autocorrelation in nonlinear models," The Review of Economics and Statistics 74(2), 370-373. DOI: 10.2307/2109675

Yousefpour, R., Didion, M., Jacobsen, J. B., Meilby, H., Hengeveld, G. M., Schelhaas, M. J., and Thorsen, B. J. (2015). "Modelling of adaptation to climate change and decision-makers behaviours for the Veluwe forest area in the Netherlands," Forest Policy and Economics 54, 1-10. DOI: 10.1016/j.forpol.2015.02.002

Article submitted: April 23, 2020; Peer review completed: June 4, 2020; Revised version received: June 9, 2020; Accepted: June 10, 2020; Published: June 15, 2020.

DOI: 10.15376/biores.15.3.5913-5925 